특발성 중심와부근 모세혈관확장증 2형과 황반망막분지정맥폐쇄의 빛간섭단층촬영 혈관조영술 양상

\title{
Optical Coherence Tomography Angiography Features of Idiopathic Macular Telangiectasia Type 2 and Macular Branch Retinal Vein Occlusion
}

\author{
안자영 ${ }^{1}$, 손준홍 ${ }^{1}$, 공민귀 ${ }^{1,2}$ \\ Jayoung Ahn ${ }^{1}$, Joon Hong Sohn ${ }^{1}$, Mingui Kong ${ }^{1,2}$ \\ 1한길안과병원, ${ }^{2}$ 가톨릭관동대학교 의과대학 안과학교실 \\ ${ }^{1}$ HanGil Eye Hospital, Incheon, Korea \\ ${ }^{2}$ Department of Ophthalmology, Catholic Kwandong University College of Medicine, Gangneung, Korea
}

Purpose: To evaluate the vascular features of patients with idiopathic macular telangiectasia type 2 (MacTel 2) and macular branch retinal vein occlusion (BRVO) through optical coherence tomography angiography (OCTA).

Methods: Medical records of patients who were initially diagnosed with MacTel 2 ( 8 eyes of 8 patients) and macular BRVO (8 eyes of 8 patients) were retrospectively reviewed. Foveal avascular zone (FAZ) area and vascular density of OCTA were analyzed by dividing the region into superficial capillary plexus (SCP) and deep capillary plexus (DCP).

Results: Comparison between the patients with MacTel 2 and macular BRVO revealed that there was no significant difference of SCP FAZ area $\left(0.44 \pm 0.11 \mathrm{~mm}^{2}\right.$ and $0.37 \pm 0.11 \mathrm{~mm}^{2}$, respectively) and DCP FAZ area $\left(0.55 \pm 0.22 \mathrm{~mm}^{2}\right.$ and $0.66 \pm 0.45 \mathrm{~mm}^{2}$, respectively). There was no significant difference in the vascular density of the SCP between the two groups. The nasal and inferior sector vascular density of DCP in patients with macular BRVO (26.05 \pm 12.18 and $23.64 \pm 10.34$, respectively) was significantly lower than that in patients with MacTel 2 (44.49 \pm 8.97 and $36.43 \pm 6.67$, respectively) $(p=0.009, p=0.027$, respectively). The SCP and the DCP vascular density in patients with macular BRVO showed a significant negative correlation with logarithm of the minimum angle of resolution (logMAR) best corrected visual acuity (BCVA) ( $p=0.013, p=0.043$, respectively).

Conclusions: Vascular density of the nasal and inferior sector of the DCP was significantly lower in patients with macular BRVO, and the BCVA in patients with macular BRVO deteriorated when the vascular density decreased.

Keywords: Foveal avascular zone; Idiopathic macular telangiectasia type 2; Macular branch retinal vein occlusion; Optical coherence tomography angiography; Vascular density

\section{서론}

1982년 Gass and Oyakawa [1]는 연관된 질환 없이 중심와부근
에 국한된 망막모세혈관의 확장을 보이는 질환을 확인하여 처 음으로 특발성 중심와부근모세혈관확장증(idiopathic macular telangiectasia)으로 명명하였고, 1993년 Gass and Blondi [2]에

\section{Address reprint requests to Mingui Kong, MD}

HanGil Eye Hospital, \#35 Bupyeong-daero, Bupyeong-gu, Incheon 21388, Korea

Tel: 82-32-503-3322, Fax: 82-32-504-3322

E-mail: eyedockong@gmail.com
Received: 2020. 3.4

Revised: 2020.3.16

Accepted: 2020. 3. 23 
의해 3그룹으로 분류되었다. 이후 Yannuzzi et al. [3]는 임상양 상, 형광안저혈관조영술(fluorescein angiography, FAG), 빛간섭 단층촬영(optical coherence tomography, OCT) 소견을 종합하여 특발성 중심와부근모세혈관확장증 1형(aneurysmal telangiectasis) 과 특발성 중심와부근모세혈관확장증 2형(perifoveal telangiectasis) 으로 간단하게 분류하였다. 특발성 중심와부근모세혈관확장증 2형은 특발성 중심와부근모세혈관확장증 중에서 가장 흔한 형 태로 주로 중년 남녀 모두에서 발생하며, 양안에 발병하지만 비 대칭적으로 나타난다[2,3]. 비증식 특발성 중심와부근모세혈관 확장증 2형에서는 질환이 진행함에 따라 망막 투명도 소실, 망 막표층의 결절침착, 직각소정맥, 망막내층의 낭포성 변화, 망막 색소상피의 안쪽 망막층으로 이동 및 증식 소견이 관찰되며, 증 식 특발성 중심와부근모세혈관확장증 2형에서 망막하 신생혈 관이 발생하며 망막하 삼출물, 망막내 또는 망막하 출혈, 섬유 혈관성 증식을 유발하면서 시력감소를 유발한다[3].

특발성 중심와부근모세혈관확장증 2형은 망막정맥폐쇄, 방 사선망막증, 포도막염 등 이차적으로 발생한 망막모세혈관 질 환과 감별이 필요하며 이 중 가장 흔한 것은 망막분지정맥폐쇄 (branch retinal vein occlusion)에 의한 모세혈관확장이다. 망막 분지정맥폐쇄는 폐쇄된 정맥 부위에 따라 주요(major) 망막분지 정맥폐쇄와 황반(macular) 망막분지정맥폐쇄로 분류된다[4]. 황 반망막분지정맥폐쇄는 황반 세정맥의 폐쇄로 정의되는 질환으 로 중심와부근에 국한된 모세혈관확장, 미세혈관류, 망막출혈, 측부혈관(collateral vessel)을 특징으로 한다[5,6]. 황반망막분지 정맥폐쇄는 이환된 범위가 좁아 신생혈관형성은 적게 발생하지 만 황반부종과 황반허혈로 시력저하가 발생하며, 치료 및 예후 가 특발성 중심와부근모세혈관확장증과는 다르므로 두 질환을 감별하는 것이 중요하다[6,7].

현재 FAG는 특발성 중심와부근모세혈관확장증 2형과 황반 망막분지정맥폐쇄를 진단하는 가장 표준적인 방법이다. $\mathrm{FAG}$ 는 망막 혈관의 혈류 흐름을 동적으로 보여줄 수 있어 조영제의 누 출(leakage), 고임(pooling), 염색(stain)의 양상을 확인할 수 있게 한다. 하지만 FAG는 2차원적 영상으로써 주로 표층모세혈관총 (superficial capillary plexus, SCP)을 보여주고 심부모세혈관총 (deep capillary plexus, DCP) 및 방사모양유두주위 모세혈관총 (peripapillary capillary plexus)은 잘 보여주지 못하여 모세혈관 총을 층별로 분리하여 나타낼 수 없다[8,9]. 또한 $\mathrm{FAG}$ 는 침습적 인 검사로 조영제 투여가 필요하며 이로 인한 오심, 구토 및 아 나필락시스 반응이 발생할 수 있다[10]. 반면 빠르게 반복되는 $\mathrm{B}$ 스캔을 통해 적혈구 신호를 구분하는 빛간섭단층촬영 혈관 조영술(optical coherence tomography angiography, OCTA)의 발 달로, 현재는 조영제 투여 없이 비침습적으로 망막모세혈관의 구조를 관찰할 수 있다[11]. 그리고 OCTA는 FAG와 달리 $\mathrm{SCP}$ 와 $\mathrm{DCP}$ 로 나누어 망막혈관 구조를 확인할 수 있으며, 조영제 누출 이 없어 중심와무혈관부위(foveal avascular zone, FAZ)를 비교
적 정확히 관찰할 수 있다[12,13]. 본 연구에서는 OCTA를 통해 특발성 중심와부근모세혈관확장증 2형과 황반망막분지정맥폐 쇄 환자의 망막혈관 양상을 단면적으로 비교하고, OCTA의 임 상적 효용성을 확인하고자 하였다.

\section{대상과 방법}

본 연구는 2017년 6월부터 2019년 6월까지 본원에 내원하여 안 저촬영, OCT, FAG, OCTA 검사를 통해 특발성 중심와부근모 세혈관확장증 2형과(Fig. 1) 황반 망막분지정맥폐쇄로(Fig. 2) 처음 진단받은 환자 16 명을 대상으로 의무기록을 후향적으로 고찰하였다. 특발성 중심와부근모세혈관확장증 2형은 양안에 서 대칭적으로 나타난 경우 우안을 대상으로 하였으며, 비대칭 적으로 나타난 경우 병변이 조금 더 명확히 관찰되는 안구를 대상으로 하였다. 또한 황반망막분지정맥폐쇄 환자는 수평솔 기(horizontal raphe)를 기준으로 폐쇄된 정맥의 위치에 따라 상 측 황반망막분지정맥폐쇄와 하측 황반망막분지정맥폐쇄 환자 로 소그룹 분류하였다.

모든 환자에서 초진 시 나이, 성별, 기저질환을 확인하고 최 대교정시력 및 안압을 측정하였으며, 세극등현미경 검사가 시 행되었다. 세극등현미경 및 안저촬영 검사에서 대상 질환 외 망 막질환, 시신경질환이 있는 경우와 전안부 혼탁으로 명확한 영 상을 얻기 힘든 경우는 대상에서 제외하였다. 또한 이전에 유리 체절제술을 포함한 망막수술, 유리체강내 주입술, 레이저광응 고술, 광역학치료를 시행한 과거력이 있는 경우도 대상에서 제 외하였다.

빛간섭단층촬영 혈관조영술은 빛간섭단층촬영기(Spectralis OCT, Heidelberg engineering, Heidelberg, Germany)를 이용하여 중심 와를 중심으로 하는 $3 \times 3 \mathrm{~mm}$ 영역을 촬영하였다. 내장된 소 프트웨어(Heidelberg Eye Explorer, version 1.10.2.0, Heidelberg Engineering, Heidelberg, Germany)를 이용하여 촬영된 $\mathrm{SCP}$ 및 $\mathrm{DCP}$ 영상을 JPG 파일로 획득하였다. 본 연구에 사용된 장비는 신경섬유층과 신경절세포층을 $\mathrm{SCP}$ 로, 내망상층으로부터 외망 상층까지를 $\mathrm{DCP}$ 로 층을 나누었다. 망막부종 등으로 인한 분할 (segmentation) 오류가 있을 경우 저자들이 수동으로 조정하였 다. $\mathrm{FAZ}$ 면적은 $\mathrm{SCP}$ 와 $\mathrm{DCP}$ 로 나누어 측정하였으며, 측정자가 모세혈관총의 경계를 따라 그리면 내장된 소프트웨어를 통해 자동으로 면적이 측정되었다(Fig. 1D, 1E, 2D, 2E). JPG 영상은 Image J (version 1.52a, National Institutes of Health, Bethesda, MA, USA)를 통해 8 bit gray scale로 변환 후 Auto Threshold algorithm (version 1.15)을 이용하여 binary image로 변환하였 다(Fig. 3) [14,15]. 이후 Image J의 Vascular analysis Plugin을 이 용하여 혈관밀도를 측정하였다. 혈관밀도는 $3 \times 3 \mathrm{~mm}$ 영역 전 체와 중심와를 중심으로 상측, 하측, 이측, 비측 영역으로 나누 
어 각 구역의 혈관밀도를 측정하였다(Fig. 3E).

통계분석은 SPSS Statistics 23.0 (IBM Corp., Armonk, NY, $\mathrm{USA})$ 을 이용하였다. 특발성 중심와부근모세혈관확장증 2형과 황반망막분지정맥폐쇄 및 상측 황반망막분지정맥폐쇄와 하측 황반망막분지정맥폐쇄의 FAZ 면적과 혈관밀도의 비교는 MannWhitney U-test를 이용하였다. 시력과 FAZ 면적, 시력과 혈관밀 도 사이의 상관관계 분석을 위해 Spearman correlation coefficient test를 이용하였다. $p$ 값은 0.05 이하인 경우 통계적으로 유의한 것 으로 판단하였다. 본 연구는 헬싱키선언(Declaration of Helsinki) 을 준수하였으며, 후향적으로 의무기록을 분석한 피험자 동의면
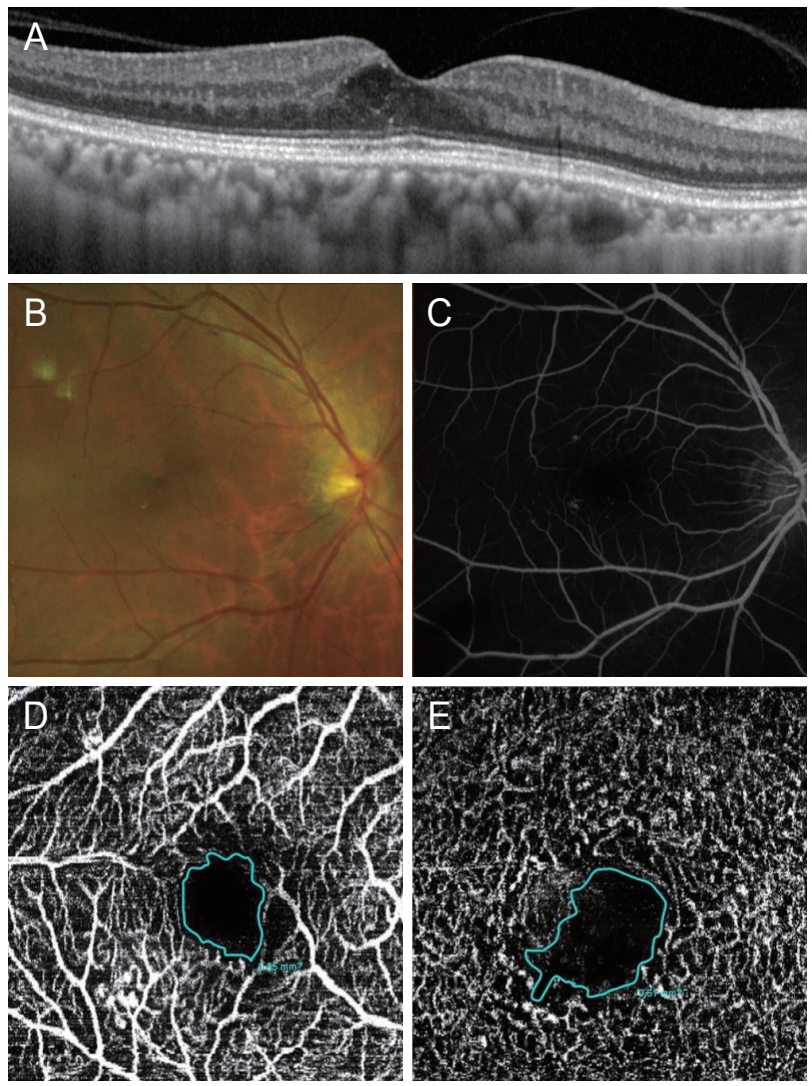

Figure 1. Images from the right eye of a 60 -year-old female patient with the diagnosis of idiopathic macular telangiectasia type 2. (A) Optical coherence tomography image shows intraretinal hyporeflective cavitation. (B) Color fundus photography shows parafoveal loss of retinal transparency. (C) Early phase fluorescein angiography shows hyperfluorescence in the temporal juxtafoveal region that represented the telangiectatic microvasculature. (D) Superficial capillary plexus optical coherence tomography angiography (OCTA) image shows a perifoveal telagiectactic microvascular abnormality. The margin of the foveal avascular zone (FAZ) is marked with a blue line, and the area is measured by the equipped software. (E) Deep capillary plexus OCTA image shows an enlarged FAZ area to the temporal perifoveal region.
제 연구로 한길안과병원 연구윤리심의위원회(Institutional Review Board, IRB) 승인을 받았다(IRB No.: 19009).

\section{결과}

특발성 중심와부근모세혈관확장증 2형 8명 8안, 황반망막분지 정맥폐쇄 8 명 8 안으로 총 16 안이 연구에 포함되었다. 초진 시 두 군 사이에 성별, 당뇨 및 고혈압 유무, 최대교정시력, 안압의 통 계적으로 유의한 차이는 없었다(Table 1). 특발성 중심와부근모
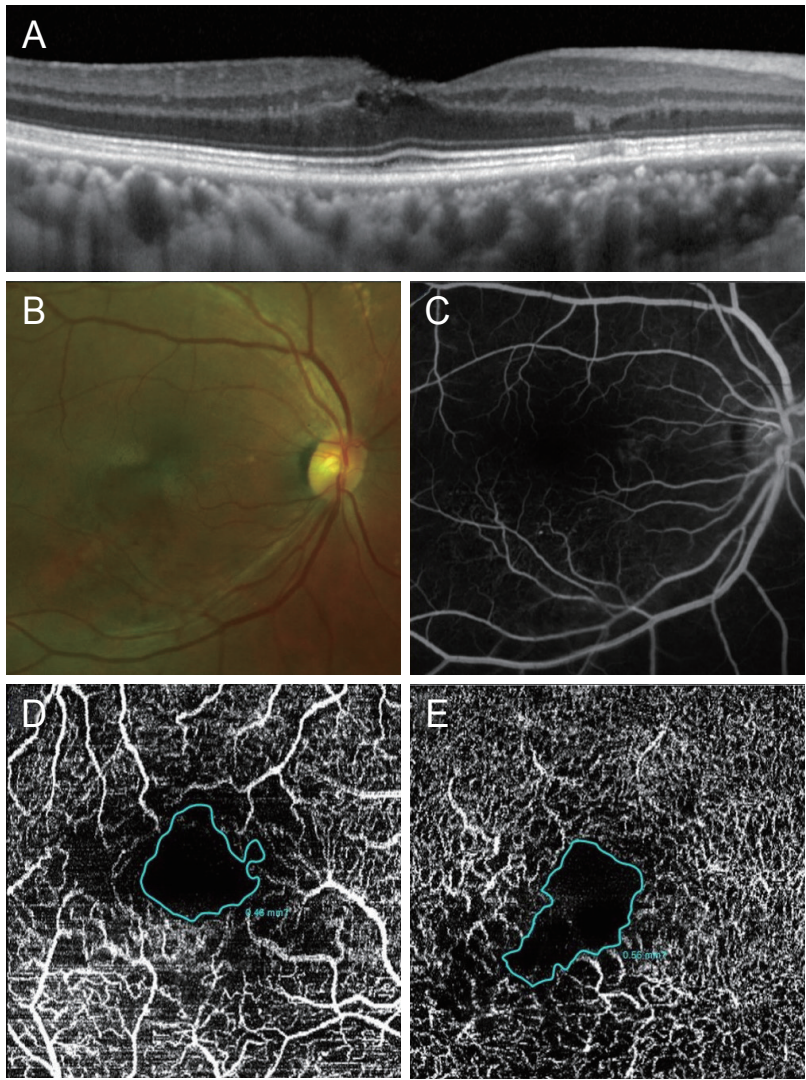

Figure 2. Images from the right eye of a 58-year-old male patient with the diagnosis of inferior macular branch retinal vein occlusion. (A) Optical coherence tomography imaging shows an intraretinal cyst and mild macular edema. (B) Color fundus photography shows retinal hemorrhage and vessel dilatation in the inferior perifoveal region. (C) Early phase fluorescein angiography shows telangiectatic vessels at the inferior perifovea. (D) Superficial capillary plexus optical coherence tomography angiography (OCTA) image shows an inferior perifoveal microvascular abnormality and collateral vessels. The margin of the foveal avascular zone (FAZ) is marked with a blue line, and the area is measured by the equipped software. (E) Deep capillary plexus OCTA image shows an enlarged FAZ area. 

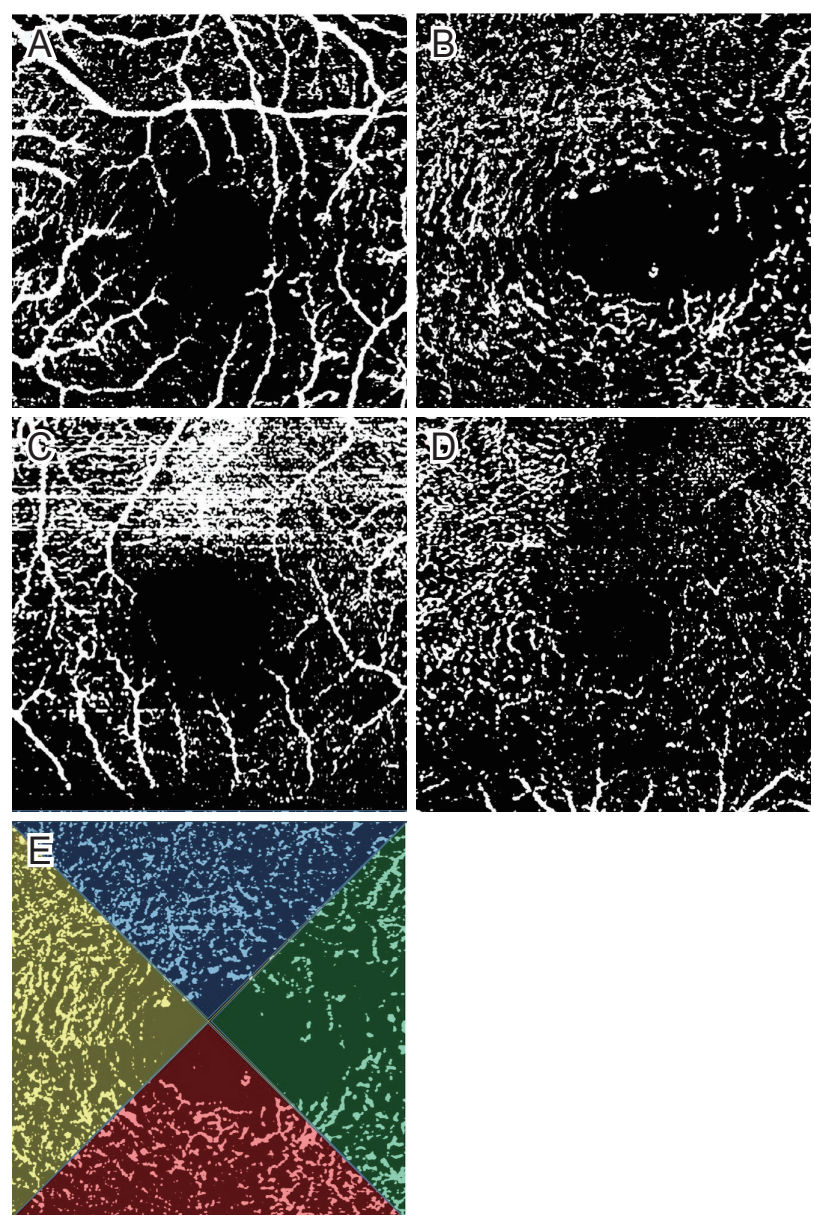

Figure 3. Optical coherence tomography angiography images are converted to an 8-bit gray scale and binary image through Image J (version 1.52a, National Institutes of Health, Bethesda, MA, USA). (A, B) Images from the left eye of a 74-year-old female patient with the diagnosis of idiopathic macular telangiectasia type 2. Superficial capillary plexus (SCP) image (A) and deep capillary plexus (DCP) image (B) shows reduced vascular density, especially in the temporal region. (C, D) Images from the right eye of a 56-year-old male patient with the diagnosis of superior macular branch retinal vein occlusion. SCP image (C) and DCP image (D) shows reduced vascular density in the diffuse area. (E) Vascular density of the left eye is measured by dividing the $3 \times 3 \mathrm{~mm}^{2}$ whole area into the superior (blue), inferior (red), temporal (green) and nasal (yellow) sectors.

세혈관확장증 2형 환자의 평균 나이는 $65.38 \pm 6.32$ 세, 황반망 막분지정맥폐쇄 황자의 평균 나이는 $54.38 \pm 8.50$ 세로 두 군 사 이에 통계적으로 유의한 차이가 관찰되었다.

특발성 중심와부근모세혈관확장증 2형 환자의 FAZ 면적은 $\mathrm{SCP}$ 에서 $0.44 \pm 0.11 \mathrm{~mm}^{2}, \mathrm{DCP}$ 에서 $0.55 \pm 0.22 \mathrm{~mm}^{2}$ 로 측 정되었으며, 황반망막분지정맥폐쇄 환자의 FAZ 면적은 SCP에 서 $0.37 \pm 0.11 \mathrm{~mm}^{2}, \mathrm{DCP}$ 에서 $0.66 \pm 0.45 \mathrm{~mm}^{2}$ 로 측정되었다
Table 1. Baseline clinical features of patients diagnosed with idiopathic MacTel 2 and macular BRVO

\begin{tabular}{lccc}
\hline Characteristic & $\begin{array}{c}\text { MacTel 2 } \\
(\mathrm{n}=8)\end{array}$ & $\begin{array}{c}\text { Macular BRVO } \\
(\mathrm{n}=8)\end{array}$ & $p$-value \\
\hline Age (years) & $65.38 \pm 6.32$ & $54.38 \pm 8.50$ & $0.005^{*}$ \\
Sex (male/female) & $3 / 5$ & $5 / 3$ & $0.619^{\dagger}$ \\
BCVA (logMAR) & $0.25 \pm 0.33$ & $0.18 \pm 0.18$ & $0.915^{*}$ \\
IOP (mmHg) & $14.63 \pm 3.46$ & $15.88 \pm 1.89$ & $0.185^{*}$ \\
Diabetes mellitus & 2 & 1 & $1.000^{\dagger}$ \\
Hypertension & 4 & 4 & $1.000^{\dagger}$ \\
\hline
\end{tabular}

Values are presented as the mean \pm standard deviation unless otherwise indicated.

MacTel 2 = macular telangiectasia type 2; BRVO = branch retinal vein occlusion; $B C V A$ = best-corrected visual acuity; logMAR = logarithm of the minimum angle of resolution; IOP = intraocular pressure.

${ }^{*} p$-value derived from Mann-Whitney $U$-test; ${ }^{\dagger} p$-value derived from Fisher's Exact test.

(Table 2). 두 군 모두 DCP FAZ 면적 평균이 SCP FAZ 면적 평 균보다 크게 측정되었으나, 통계적으로 유의한 차이는 없었다 (각각 $p=0.156, p=0.065$ ). 특발성 중심와부근모세혈관확장 증 2형 환자와 황반망막분지정맥폐쇄 환자 사이에 FAZ 면 적은 $\mathrm{SCP}$ 와 $\mathrm{DCP}$ 에서 유의한 차이는 없었다(각각 $p=0.227$, $p=0.833$.

$\mathrm{SCP}$ 의 혈관밀도 측정에서 특발성 중심와부근모세혈관확장증 2 형 환자는 영역 전체 $40.85 \pm 8.46 \%$, 이측 $38.84 \pm 8.55 \%$, 상 측 $40.24 \pm 10.74 \%$, 비측 $44.51 \pm 8.03 \%$, 하측 $39.42 \pm 10.03 \%$ 로 이측에서 가장 낮게 측정되었고, 황반망막분지정맥폐쇄 환 자는 영역 전체 $36.87 \pm 11.22 \%$, 이측 $33.82 \pm 11.15 \%$, 상측 $32.78 \pm 10.57 \%$, 비측 $40.31 \pm 13.90 \%$, 하측 $35.69 \pm 15.03 \%$ 로 상측에서 가장 낮게 측정되었으나 두 군 사이에 의미 있는 차 이는 없었다(Table 2).

$\mathrm{DCP}$ 의 혈관밀도 측정에서 특발성 중심와부근모세혈관확장 증 2형 환자는 영역 전체 $37.88 \pm 8.63 \%$, 이측 $33.39 \pm 12.52 \%$, 상측 $37.36 \pm 9.50 \%$, 비측 $44.49 \pm 8.97 \%$, 하측 $36.43 \pm 6.67 \%$ 로 $\mathrm{SCP}$ 에서와 같이 이측에서 가장 낮게 측정되었고, 황반망 막분지정맥폐쇄 환자는 영역 전체 $27.26 \pm 9.93 \%$, 이측 30.74 $\pm 10.83 \%$, 상측 $28.62 \pm 12.40 \%$, 비측 $26.05 \pm 12.18 \%$, 하측 $23.64 \pm 10.34 \%$ 로 하측에서 가장 낮게 측정되었다(Table 2). 두 군 간의 비교에서 황반망막분지정맥폐쇄 환자의 비측 및 하 측 영역 혈관밀도가 특발성 중심와부근모세혈관확장증 2형 환 자보다 통계적으로 유의하게 낮게 측정되었다(각각 $p=0.009$, $p=0.027$.

하측 황반망막분지정맥폐쇄 환자 4 명 4 안, 상측 황반망막분지 정맥폐쇄 환자 4 명 4 안이 소그룹으로 분류되었다. 두 소그룹 사 
Table 2. FAZ area and vascular density of the SCP and the DCP evaluated by OCTA in patients with idiopathic MacTel 2 and macular BRVO

\begin{tabular}{lccc}
\hline Variable & $\begin{array}{c}\text { Patients with } \\
\text { MacTel 2 }\end{array}$ & $\begin{array}{c}\text { Patients with } \\
\text { macular BRVO }\end{array}$ & p-value \\
\hline $\begin{array}{l}\text { FAZ area }\left(\mathrm{mm}^{2}\right) \\
\text { SCP }\end{array}$ & $0.44 \pm 0.11$ & $0.37 \pm 0.11$ & 0.227 \\
DCP & $0.55 \pm 0.22$ & $0.66 \pm 0.45$ & 0.833 \\
$\quad$ p-value & 0.156 & 0.065 & \\
Vascular density of & & & \\
the SCP (\%) & & & \\
Whole & $40.85 \pm 8.46$ & $36.87 \pm 11.22$ & 0.462 \\
Temporal & $38.84 \pm 8.55$ & $33.82 \pm 11.15$ & 0.401 \\
Superior & $40.24 \pm 10.74$ & $32.78 \pm 10.57$ & 0.172 \\
Nasal & $44.51 \pm 8.03$ & $40.31 \pm 13.90$ & 0.753 \\
Inferior & $39.42 \pm 10.03$ & $35.69 \pm 15.03$ & 0.600 \\
Vascular density of & & & \\
the DCP (\%) & & & \\
$\quad$ Whole & $37.88 \pm 8.63$ & $27.26 \pm 9.93$ & 0.074 \\
$\quad$ Temporal & $33.39 \pm 12.52$ & $30.74 \pm 10.83$ & 0.600 \\
Superior & $37.36 \pm 9.50$ & $28.62 \pm 12.40$ & 0.294 \\
Nasal & $44.49 \pm 8.97$ & $26.05 \pm 12.18$ & 0.009 \\
Inferior & $36.43 \pm 6.67$ & $23.64 \pm 10.34$ & 0.027 \\
\hline
\end{tabular}

Values are presented as the mean \pm standard deviation.

$F A Z$ = foveal avascular zone; SCP = superficial capillary plexus; DCP = deep capillary plexus; OCTA = optical coherence tomography angiography; MacTel 2 = macular telangiectasia type 2; BRVO = branch retinal vein occlusion.

${ }^{*}$ Comparison between MacTel 2 and Macular BRVO. $p$-value derived from Mann-Whitney $U$-test; ${ }^{\dagger}$ comparison between SCP and DCP FAZ area in each group. $p$-value derived from Mann-Whitney U-test.

이에 SCP와 DCP의 혈관밀도는 상측, 하측, 이측, 비측 모든 영 역에서 유의한 차이가 없었다(Table 3).

특발성 중심와부근모세혈관확장증 2형 환자와 황반망막분 지정맥폐쇄 환자의 SCP 및 DCP의 FAZ 면적과 logarithm of the minimum angle of resolution (logMAR) 최대교정시력과의 연관성 을 조사하였을 때 유의한 상관관계는 관찰되지 않았다(Table 4). 혈관밀도와 최대교정시력과의 연관성을 분석했을 때 황반망 막분지정맥폐쇄 환자에서 $\mathrm{SCP}$ 의 혈관밀도와 $\mathrm{DCP}$ 의 혈관밀 도가 $\log \mathrm{MAR}$ 최대교정시력과 음의 상관관계를 보였으며(각각 rho $=-0.819$, rho $=-0.723)$ 이는 통계적으로 유의하였다(각각 $p=0.013, p=0.043$ (Table 4). 특발성 중심와부근모세혈관확장 증 2형 환자에서는 혈관밀도와 최대교정시력과의 유의한 상관 관계를 확인할 수 없었다.
Table 3. Vascular density of the SCP and the DCP evaluated by OCTA in patients with inferior macular and superior macular BRVO

\begin{tabular}{|c|c|c|c|}
\hline Variable & $\begin{array}{c}\text { Inferior macular } \\
\text { BRVO }(n=4)\end{array}$ & $\begin{array}{c}\text { Superior macular } \\
\text { BRVO }(n=4)\end{array}$ & $p$-value ${ }^{*}$ \\
\hline \multicolumn{4}{|c|}{$\begin{array}{l}\text { Vascular density of } \\
\text { the SCP (\%) }\end{array}$} \\
\hline Whole & $41.15 \pm 12.78$ & $32.59 \pm 9.04$ & 0.564 \\
\hline Temporal & $35.95 \pm 14.74$ & $31.70 \pm 7.80$ & 0.386 \\
\hline Superior & $32.95 \pm 12.27$ & $32.61 \pm 10.48$ & 1.000 \\
\hline Nasal & $47.66 \pm 9.50$ & $32.97 \pm 14.71$ & 0.149 \\
\hline Inferior & $39.30 \pm 17.95$ & $32.08 \pm 13.05$ & 0.564 \\
\hline \multicolumn{4}{|c|}{$\begin{array}{l}\text { Vascular density of } \\
\text { the DCP (\%) }\end{array}$} \\
\hline Whole & $29.57 \pm 10.49$ & $24.94 \pm 10.29$ & 0.386 \\
\hline Temporal & $34.04 \pm 10.06$ & $27.44 \pm 11.99$ & 0.564 \\
\hline Superior & $33.53 \pm 12.82$ & $23.70 \pm 11.42$ & 0.149 \\
\hline Nasal & $27.12 \pm 16.06$ & $24.99 \pm 9.25$ & 0.773 \\
\hline Inferior & $23.12 \pm 9.87$ & $24.16 \pm 12.30$ & 1.000 \\
\hline
\end{tabular}

Values are presented as mean \pm standard deviation.

SCP = superficial capillary plexus; DCP = deep capillary plexus; OCTA = optical coherence tomography angiography; BRVO = branch retinal vein occlusion.

" $p$-value derived from Mann-Whitney U-test.

Table 4. Correlation between logMAR best corrected visual acuity and OCTA parameters in patients with idiopathic Mactel 2 and macular BRVO

\begin{tabular}{lcc}
\hline Variable & Mactel 2 & Macular BRVO \\
\hline FAZ area $\left(\mathrm{mm}^{2}\right)$ & & \\
$\quad$ SCP & $0.565(0.145)$ & $-0.096(0.820)$ \\
DCP & $0.614(0.106)$ & $0.301(0.468)$ \\
Whole area Vascular density (\%) & & \\
SCP & $-0.368(0.369)$ & $-0.819(0.013)$ \\
DCP & $-0.295(0.479)$ & $-0.723(0.043)$ \\
\hline
\end{tabular}

Values are presented as rho ( $p$-value). Rho and $p$-value derived from Spearman's correlation coefficient test.

$\log M A R=$ logarithm of the minimum angle of resolution; OCTA = optical coherence tomography angiography; Mactel 2 = macular telangiectasia type 2; BRVO = branch retinal vein occlusion; FAZ $=$ foveal avascular zone; $\mathrm{SCP}=$ superficial capillary plexus; $\mathrm{DCP}=$ deep capillary plexus. 


\section{고찰}

망막중심동맥은 분지를 내면서 망막의 주변부까지 혈액을 공급 하는데, 황반의 중심에 직경 $0.5 \mathrm{~mm}$ 의 FAZ를 형성한다. 지금 까지 당뇨망막병증, 망막정맥폐쇄 등의 망막질환에서 FAZ 면적 이 넓어지는 것으로 보고되었으며, FAZ 면적과 모양은 시력과 관련이 있는 것으로 보고되었다[16-19]. 정상 한국인을 대상으 로 시행한 OCTA 결과를 분석한 이전 연구에서 $\mathrm{SCP}$ 의 FAZ 면 적은 $0.32 \pm 0.11 \mathrm{~mm}^{2}, 0.35 \pm 0.10 \mathrm{~mm}^{2}$ 로 측정되었고, $\mathrm{DCP}$ 의 FAZ 면적은 $0.41 \pm 0.14 \mathrm{~mm}^{2}, 0.44 \pm 0.11 \mathrm{~mm}^{2}$ 로 측정되어 $\mathrm{DCP}$ 의 FAZ 면적의 평균이 더 큰 것으로 보고되었다[20,21]. 모 세혈관총은 중심와에서 고리 모양으로 연결되어 $\mathrm{FAZ}$ 를 형성하 는데, DCP에서는 SCP에 비해 연속적이지 못한 고리 모양을 형 성하여 이러한 결과를 나타낼 수 있다[22,23].

본 연구에서 특발성 중심와부근모세혈관확장증 2형 환자의 FAZ 면적의 평균은 $\mathrm{DCP}(0.55 \pm 0.22)$ 에서 $\mathrm{SCP}(0.44 \pm 0.11)$ 보다 크게 측정되었다. Dogan et al. [24]도 특발성 중심와부근 모세혈관확장증 2형 환자에서 유사한 결과를 보고하였으며, 정 상 대조군과 비교하여 DCP의 FAZ 면적은 유의하게 큰 것으로 보고하였다. 특발성 중심와부근모세혈관확장증 2형에서의 모 세혈관 확장 및 소실 등의 이상 소견은 DCP에서부터 시작해서 $\mathrm{SCP}$ 로 진행되고 $\mathrm{DCP}$ 에서 현저하게 나타나는 것으로 보고되었 으며[25], 따라서 FAZ 면적도 DCP에서 더 크게 측정되는 것으 로 보인다. 또한 황반망막분지정맥폐쇄 환자에서도 DCP의 FAZ 면적의 평균(0.66 \pm 0.45$)$ 이 SCP의 FAZ 면적 평균(0.37 \pm 0.11$)$ 보다 크게 측정되었다. 망막분지정맥폐쇄로 인한 혈관내압의 증 가는 모세혈관의 관류 감소를 유발하며 이로 인해 FAZ의 면적 이 커질 수 있다. 하지만 $\mathrm{SCP}$ 는 망막동맥에 직접 연결되어 있어 관류압이 높게 유지되고 모세혈관이 더 잘 보존될 수 있어[26], $\mathrm{DCP}$ 보다 FAZ 면적 확대가 작을 수 있다. 본 연구에서 두 군 모 두 DCP FAZ 면적 평균이 SCP FAZ 면적 평균보다 크게 측정되 었으나 통계적으로 유의하지는 않았으며, 이전 연구에서도 SCP 와 DCP의 FAZ 면적에 대한 통계적 비교는 없었다. 향후 더 많 은 환자를 대상으로 한 추가적인 연구를 통해 통계적 유의성 확 인이 필요할 것으로 생각된다. 그리고 본 연구에서 특발성 중심 와부근모세혈관확장증 2형 환자와 황반망막분지정맥폐쇄 환자 사이에 FAZ 면적의 유의한 차이는 없었다. 이는 두 질환 모두 정상안과 비교 시 유의한 FAZ 면적의 확대가 이전 연구에서 관 찰되었고[7,24], 따라서 두 군 사이의 비교에서는 통계적으로 유 의한 차이를 보이지 않은 것으로 생각된다.

특발성 중심와부근모세혈관확장증 2형 환자의 검사 영역 전 체 혈관밀도는 $\mathrm{DCP}(37.88 \pm 8.63)$ 에서 $\mathrm{SCP}(40.85 \pm 8.46)$ 보다 낮게 측정되었으며, 두 층 모두 이측에서 혈관밀도가 가장 낮게 측정되었다. 그리고 특발성 중심와부근모세혈관확장증 2형 환 자의 OCTA상 모세혈관 확장은 주로 이측에서 나타났으며, FAZ
또한 대부분 이측으로 확대되는 경향을 보였다(Fig. 1D, E). 본 연구는 연구기간 내 본원에서 처음으로 질환을 진단받은 환자 를 대상으로 진행되었으며, 특발성 중심와부근모세혈관확장증 2형 환자는 모두 비증식 단계였다. 앞서 언급한 바와 같이 특발 성 중심와부근모세혈관확장증 2형의 초기 혈관이상은 $\mathrm{DCP}$ 에 서 나타나며 또한 이측 중심와부(parafovea)에서 시작되어 중심 와를 중심으로 주변으로 진행하는 것으로 알려져 있다[25,27]. Dogan et el. [24]은 특발성 중심와부근모세혈관확장증 2형 환자 의 OCTA 검사상 DCP에서 중심와부 영역 전체와 이측의 혈관 밀도가 정상 대조군과 비교하여 유의하게 낮은 것으로 보고하 였으며, 이는 본 연구의 결과와도 유사하였다. 황반망막분지정 맥폐쇄 환자에서도 DCP의 영역 전체 혈관밀도(27.26 \pm 9.93)가 $\mathrm{SCP}$ 의 영역 전체 혈관밀도(36.87 \pm 11.22$)$ 보다 낮게 측정되었 다. 지금까지 황반망막분지정맥폐쇄 환자만을 대상으로 OCTA 상 혈관밀도를 측정한 연구는 없었으나, 망막정맥폐쇄 환자를 대상으로 시행한 연구에서도 DCP가 SCP보다 허혈성 변화에 더 취약한 것으로 보고되었다[28]. 두 군 사이의 비교에서는 황반 망막분지정맥폐쇄 환자 $\mathrm{DCP}$ 의 비측 및 하측에서의 혈관밀도가 통계적으로 유의하게 낮게 측정되었다. 이는 특발성 중심와부 근모세혈관확장증 2형 환자의 경우 주로 이측에서 혈관밀도가 감소하였으나, 황반망막분지정맥폐쇄 환자의 경우 전체 영역에 걸쳐 혈관밀도가 감소하였으며 특히 DCP에서의 허혈성 변화가 더 크게 나타났기 때문이라고 설명할 수 있다.

상측 황반망막분지정맥폐쇄 환자와 하측 황반망막분지정맥 폐쇄 환자의 혈관밀도 비교에서, 상측, 하측, 이측, 비측의 모든 영역에서 두 소그룹 사이에 통계적으로 유의한 혈관밀도 차이 는 없었다. 망막정맥폐쇄 환자에서 고혈압, 당뇨, 동맥경화증, 흡연은 더 흔히 관찰되는 것으로 알려져 있으며[29,30], 이러한 전신질환은 망막동맥의 경화를 유발하여 동정맥교차부에서의 정맥압박이 발생한다. 망막분지정맥폐쇄가 발생하기 전 이러한 해부학적 변화는 이미 존재하는 것으로 볼 수 있으며, 따라서 황반망막분지정맥폐쇄 환자는 폐쇄된 정맥의 위치와 관계없이 $3 \times 3 \mathrm{~mm}$ 영역 내 혈관밀도는 전체적으로 감소되는 것으로 사 료된다. 하지만 본 연구는 상측 황반망막분지정맥폐쇄 4 안과, 하 측 황반망막분지정맥폐쇄 4 안 사이의 비교로 모집단의 수가 적 어 통계적 유의성이 낮게 측정되었을 가능성을 배제할 수 없다.

황반망막분지정맥폐쇄 환자에서 황반허혈은 시력저하의 주 요 원인으로 알려져 있지만[6,7], 특발성 중심와부근모세혈관확 장증 2형 환자는 증식 단계에서 발생하는 망막하 삼출물, 망 막내 또는 망막하 출혈, 섬유혈관성 증식으로 급격한 시력저하 가 발생한다[3]. 따라서 OCTA에서 관찰되는 허혈성 변화와 시 력과의 상관관계는 특발성 중심와부근모세혈관확장증 2형 환 자보다 황반망막분지정맥폐쇄 환자에서 더 관련성이 높다. 본 연구의 상관관계 분석에서도 황반망막분지정맥폐쇄 환자의 혈 관밀도와 $\log \mathrm{MAR}$ 최대교정시력 사이에 통계적으로 유의한 음 
의 상관관계가 관찰되었으며, 혈관밀도가 감소될 때 시력이 악 화됨을 확인하였다. 하지만 FAZ 면적과 최대교정시력과의 유의 한 상관관계는 나타나지 않았다. Parodi et al. [7]은 황반망막분 지정맥폐쇄 환자에서 FAG상 FAZ와 시력과의 유의한 상관관 계가 있음을 보고하였고, Kang et al. [18]은 망막정맥폐쇄 환 자에서 $\mathrm{OCTA}$ 상 $\mathrm{SCP}$ 의 FAZ와 시력과의 유의한 상관관계가 있 음을 보고하였다. 하지만 앞선 두 연구는 질병이 진행된 환자 를 포함하여 시행되었으나 본 연구는 본원에서 처음 진단받았 으며 이전에 치료를 시행한 병력이 없는 환자만을 대상으로 하 였다. 따라서 저자들은 황반망막분지정맥폐쇄의 초기에 시력을 반영하는 지표로써 혈관밀도가 FAZ 면적보다 더욱 유용할 것 으로 생각한다.

본 연구의 제한점은 질환의 특성상 연구 대상안의 수가 적었 다. 따라서 향후 대상자를 추가한 후속 연구를 통해 본 연구에 서 확인된 차이에 대한 재확인이 필요할 것으로 사료된다. 또한 본 연구는 정상 대조군이 없어 정상안과 두 질환과의 차이를 확 인할 수 없었다. 향후 반대안을 정상 대조군으로 한 전향적 코 호트 연구가 도움이 될 것으로 생각된다. 그리고 후향적 연구로 인한 제한점으로 두 군 사이에 평균 나이의 유의한 차이가 있 었다. 하지만 정상 한국인을 대상으로 연령에 따라 OCTA 결과 를 분석한 연구에서 FAZ 면적은 나이가 증가함에 따라 증가하 였지만 50 대와 60 대 사이에의 차이는 없었으며, 혈관밀도는 연 령군 간에 차이를 보이지 않았다[20].

이러한 제한점에도 불구하고 본 연구는 특발성 중심와부근 모세혈관확장증 2형과 황반망막분지정맥폐쇄 환자의 망막혈관 양상을 OCTA를 이용하여 정량적으로 비교한 첫 연구로 두 질 환의 초기 특징을 이해하는 데 도움이 될 것으로 사료된다. 본 연구에서 $\mathrm{DCP}$ 의 비측 및 하측 영역 혈관밀도가 황반망막분지 정맥폐쇄 환자에서 유의하게 낮게 측정됨을 확인하였으며, 황 반망막분지정맥폐쇄 환자는 폐쇄된 정맥의 위치와 관계없이 검 사 영역 내 혈관밀도는 전체적으로 감소되는 것을 확인하였다. 또한 황반망막분지정맥폐쇄 환자의 혈관밀도와 $\log \mathrm{MAR}$ 최대 교정시력 사이에 통계적으로 유의한 음의 상관관계가 있음을 확인하였다.

\section{Conflicts of Interest}

The authors declare no conflicts of interest relevant to this article.

\section{References}

1. Gass JD, Oyakawa RT. Idiopathic juxtafoveolar retinal telangiectasis. Arch Ophthalmol 1982;100:769-80.
2. Gass JDM, Blodi BA. Idiopathic juxtafoveolar retinal telangiectasis. Update of classification and follow-up study. Ophthalmology 1993;100:1536-46.

3. Yannuzzi LA, Bardal AM, Freund KB, et al. Idiopathic macular telangiectasia. Arch Ophthalmol 2006;124:450-60.

4. Orth DH, Patz A. Retinal branch vein occlusion. Surv Ophthalmol 1978;22:357-76.

5. Hayreh SS, Zimmerman MB, Podhajsky P. Incidence of various types of retinal vein occlusion and their recurrence and demographic characteristics. Am J Ophthalmol 1994;117:429-41.

6. Joffe L, Goldberg RE, Magargal LE, Annesley WH. Macular branch vein occlusion. Ophthalmology 1980;87:91-8.

7. Parodi MB, Visintin F, Della Rupe P, Ravalico G. Foveal avascular zone in macular branch retinal vein occlusion. Int Ophthalmol 1995;19:25-8.

8. Spaide RF, Klancnik JM Jr, Cooney MJ. Retinal vascular layers imaged by fluorescein angiography and optical coherence tomography angiography. JAMA Ophthalmol 2015;133:45-50.

9. Mendis KR, Balaratnasingam C, Yu P, et al. Correlation of histologic and clinical images to determine the diagnostic value of fluorescein angiography for studying retinal capillary detail. Invest Ophthalmol Vis Sci 2010;51:5864-9.

10. Yannuzzi LA, Rohrer KT, Tindel LJ, et al. Fluorescein angiography complication survey. Ophthalmology 1986;93:611-7.

11. Zhang A, Zhang Q, Chen CL, Wang RK. Methods and algorithms for optical coherence tomography-based angiography: a review and comparison. J Biomed Opt 2015;20:100901.

12. Savastano MC, Lumbroso B, Rispoli MJR. In vivo characterization of retinal vascularization morphology using optical coherence tomography angiography. Retina 2015;35:2196-203.

13. Takase N, Nozaki M, Kato A, et al. Enlargement of foveal avascular zone in diabetic eyes evaluated by en face optical coherence tomography angiography. Retina 2015;35:2377-83.

14. Hartig SM. Basic image analysis and manipulation in Image J. Curr Protoc Mol Biol 2013;102:1-12.

15. Shahlaee A, Samara WA, Hsu J, et al. In vivo assessment of macular vascular density in healthy human eyes using optical coherence tomography angiography. Am J Ophthalmol 2016;165:3946.

16. Hwang TS, Jia Y, Gao SS, et al. Optical coherence tomography angiography features of diabetic retinopathy. Retina 2015;35:2371-6.

17. Conrath J, Giorgi R, Raccah D, Ridings B. Foveal avascular zone in diabetic retinopathy: quantitative vs qualitative assessment. Eye (Lond) 2005;19:322-6. 
18. Kang JW, Yoo R, Jo YH, Kim HC. Correlation of microvascular structures on optical coherence tomography angiography with visual acuity in retinal vein occlusion. Retina 2017;37:1700-9.

19. Balaratnasingam C, Inoue $M, A h n S$, et al. Visual acuity is correlated with the area of the foveal avascular zone in diabetic retinopathy and retinal vein occlusion. Ophthalmology 2016;123:235267.

20. Noh D, Ryu G, Sagong M. Analysis of foveal microvascular structures using optical coherence tomography angiography in age-stratified healthy Koreans. J Korean Ophthalmol Soc 2017;58:1058-65.

21. Im JC. Measurement of vessel density using optical coherence tomography-angiography in normal subjects: difference by analysis area. J Korean Ophthalmol Soc 2019;60:355-61.

22. Gadde SG, Anegondi N, Bhanushali D, et al. Quantification of vessel density in retinal optical coherence tomography angiography images using local fractal dimension. Invest Ophthalmol Vis Sci 2016;57:246-52.

23. Mammo Z, Balaratnasingam C, Yu P, et al. Quantitative noninvasive angiography of the fovea centralis using speckle variance optical coherence tomography. Invest Ophthalmol Vis Sci 2015;56:5074-86.
24. Dogan B, Erol MK, Akidan M, et al. Retinal vascular density evaluated by optical coherence tomography angiography in macular telangiectasia type 2. Int Ophthalmol 2019;39:2245-56.

25. Roisman L, Rosenfeld PJ. Optical coherence tomography angiography of macular telangiectasia type 2. Dev Ophthalmol 2016;56:146-58.

26. Martinet V, Guigui B, Glacet-Bernard A, et al. Macular edema in central retinal vein occlusion: correlation between optical coherence tomography, angiography and visual acuity. Int Ophthalmol 2012;32:369-77.

27. Spaide RF, Suzuki M, Yannuzzi LA, et al. Volume-rendered angiographic and structural optical coherence tomography angiography of macular telangiectasia type 2. Retina 2017;37:424-35.

28. Coscas F, Glacet-Bernard A, Miere A, et al. Optical coherence tomography angiography in retinal vein occlusion: evaluation of superficial and deep capillary plexa. Am J Ophthalmol 2016;161:160-71.e1-2

29. Wong TY, Scott IU. Clinical practice. Retinal-vein occlusion. N Engl J Med 2010;363:2135-44.

30. Klein R, Klein BE, Moss SE, Meuer SM. The epidemiology of retinal vein occlusion: the Beaver Dam Eye Study. Trans Am Ophthalmol Soc 2000;98:133-43.

\section{국문초록}

\section{특발성 중심와부근 모세혈관확장증 2형과 황반망막분지정맥폐쇄의 빛간섭단층촬영 혈관조영술 양상}

목적: 빛간섭단층촬영 혈관조영술을 통해 특발성 중심와부근모세혈관확장증 2형과 황반망막분지정맥폐쇄 환자의 망막혈관 양상을 확인 하고자 하였다.

대상과 방법: 특발성 중심와부근모세혈관확장증 2형(8명 8안)과 황반망막분지정맥폐쇄(8명 8안)로 처음 진단받은 환자를 대상으로 의 무기록을 후향적으로 고찰하였다. 빛간섭단층촬영 혈관조영술 검사상 중심와무혈관부위 면적과 혈관밀도를 표층모세혈관총과 심부모 세혈관총으로 나누어 분석하였다.

결과: 특발성 중심와부근모세혈관확장증 2형과 황반망막분지정맥폐쇄 사이에 중심와무혈관부위 면적은 표층모세혈관총(각각 $0.44 \pm$ $0.11 \mathrm{~mm}^{2}, 0.37 \pm 0.11 \mathrm{~mm}^{2}$ )과 심부모세혈관총(각각 $0.55 \pm 0.22 \mathrm{~mm}^{2}, 0.66 \pm 0.45 \mathrm{~mm}^{2}$ )에서 유의한 차이는 없었다. 표 층모세혈관총의 혈관밀도는 두 군 사이에 유의한 차이가 없었다. 황반망막분지정맥폐쇄 환자 심부모세혈관총의 비측 및 하측 영역 혈관 밀도가(각각 $26.05 \pm 12.18,23.64 \pm 10.34$ ), 특발성 중심와부근모세혈관확장증 2형 환자보다(각각 44.49 \pm 8.97, $36.43 \pm$ $6.67)$ 통계적으로 유의하게 낮았다(각각 $p=0.009, p=0.027$ ). 황반망막분지정맥폐쇄 환자에서 표층모세혈관총의 혈관밀도와 심 부모세혈관총의 혈관밀도는 $\log M A R$ 최대교정시력과 유의한 음의 상관관계를 보였다(각각 $p=0.013, p=0.043$.

결론: 심부모세혈관총의 비측 및 하측 영역 혈관밀도가 황반망막분지정맥폐쇄 환자에서 유의하게 낮으며 황반망막분지정맥폐쇄 환자는 혈관밀도가 감소될 때 시력이 악화됨을 확인하였다. 